\title{
PERSEPSI WANITA PESISIR TERHADAP MANFAAT PELATIHAN PENGOLAHAN HASIL PERIKANAN DALAM MENINGKATKAN PENDAPATAN KELUARGA
}

\author{
COASTAL WOMEN'S PERCEPTION ON THE BENEFITS OF FISHERIES \\ PROCESSING TRAINING PROGRAMS IN INCREASING FAMILY INCOME
}

\author{
Pola S.T. Panjaitan* \\ Politeknik Kelautan dan Perikanan Karawang, Jalan Lingkar Tanjungpura, Karangpawitan, Kecamatan \\ Karawang Barat, Kabupaten Karawang, Jawa Barat 41315
}

Teregistrasi I tanggal: 06 Mei 2020; Diterima setelah perbaikan tanggal: 09 Januari 2021; Disetujui terbit tanggal: 24 Januari 2021

\begin{abstract}
ABSTRAK
Peranan wanita di pesisir sebagai isteri nelayan, isteri pembudidaya ikan, dan isteri pengolah ikan diharapkan mampu menggerakkan perekonomian di pesisir dengan mengolah serta memberikan nilai tambah pada hasil produk perikanan. Tujuan penelitian ini adalah mengetahui persepsi wanita pesisir terhadap manfaat pelatihan pengolahan hasil perikanan. Pelatihan pengolahan hasil perikanan dilakukan di Balai Pendidikan dan Pelatihan Perikanan Medan (BPPP Medan). Pengumpulan data melalui survei dan observasi, dengan pemilihan secara sengaja (purposive sampling) terhadap sample yang akan diuji. Lokasi penelitian di Provinsi Aceh, Provinsi Sumatera Utara dan Provinsi Riau/Kepulauan Riau. Populasi penelitian merupakan mantan peserta pelatihan pengolahan hasil perikanan Tahun 2015-2016, sedangkan pemilihan responden dilakukan dengan teknik purposive sampling. Hasil penelitian memperlihatkan bahwa sebanyak $71,2 \%$ responden menyatakan bahwa materi pelatihan sangat bermanfaat dan dapat diterapkan dalam usaha pengolahan ikan, sebanyak $69,7 \%$ responden sudah memanfaatkan kelembagaan perbankan, sebanyak 78,4\% responden memiliki pendapatan di atas rata-rata Upah Minimum Regional (UMR) Provinsi tahun 2017, yaitu; Provinsi Aceh Rp 2.791.000, Provinsi Sumatera Utara Rp 2.152.500, dan Provinsi Riau/Kepulauan Riau Rp 2.825.200. Meningkatnya keterampilan dan pengetahuan wanita pesisir dalam berusaha menunjukkan bahwa keberhasilan kelompok wanita pesisir pasca pelatihan pengolahan hasil perikanan yang dilakukan di BPPP Medan memberikan persepsi yang positip terhadap manfaat pelatihan.
\end{abstract}

Kata kunci: persepsi, wanita pesisir, pelatihan pengolahan hasil perikanan.

\section{ABSTRACT}

The role of women on the coast as fishermen's wives, fish cultivators' wives, and fish processing wives is expected to be able to drive the economy on the coast by processing and providing added value to fishery products. The purpose of this study is the perception of women's perceptions of the benefits of fishery product processing management. Fishery product processing training is conducted at the Medan Fisheries Education and Training Center (BPPP Medan). Data collection through and observation, with purposive sampling of the sample to be tested. The research locations were in Aceh Province, North Sumatra Province and Riau / Riau Islands Province. The research population was former participants of fishery product training in 2015-2016, while the

Korespondensi penulis:

*Email: *polapanjaitan@ymail.com

DOI: http://dx.doi.org/10.15578/plgc.v2i1.8902 
selection of respondents was done by using purposive sampling technique. The results of the study were $71.2 \%$ of respondents who stated that the training material was very useful and could be applied in the fish processing business, as many as $69.7 \%$ of respondents had used banking institutions, as many as 78.4\% of respondents who had an income above the average Minimum Wage Provincial Region (UMR) in 2017, namely; Aceh Province Rp 2,791,000, North Sumatra Province Rp 2,152,500, and Riau Province / Riau Islands Rp 2,825,200. The increased skills and knowledge of women who try to show that reports from coastal communities after the fishery product training conducted at BPPP Medan give positive perceptions of the benefits of training.

Keywords: perception, coastal women, fishery product processing training

\section{PENDAHULUAN}

Wanita pesisir memegang peran penting dalam mendukung penciptaan nilai tambah hasil perikanan. Peranan wanita di pesisir sebagai isteri nelayan, isteri pembudidaya ikan, dan isteri pengolah ikan diharapkan mampu menggerakkan perekonomian di pesisir dengan mengolah serta memberikan nilai tambah pada hasil perikanan. Partisipasi wanita pesisir secara ekonomi mampu meningkatkan taraf hidup dan pendapatan keluarga serta meningkatkan wawasan berfikir yang lebih luas. Kesulitan ekonomi memaksa kaum perempuan dari kelas ekonomi rendah untuk ikut berperan dalam meningkatkan pendapatan keluarganya dengan bekerja di luar sektor domestik. Keterlibatan perempuan dalam sektor domestik memang dianggap sebagai peran kodrati sebagai ibu rumah tangga dan keterlibatan mereka di sektor publik disebut sebagai peran ganda, (Raodah, 2013).

Berdasarkan kondisi dan permasalahan yang demikian maka wanita pesisir perlu ditingkatkan keterampilan dan pengetahuannya melalui pelatihan yang banyak memberikan praktek keterampilan di samping pengetahuan yang harus dimiliki dalam mendukung usaha yang dilakukan agar dapat berkembang dan bahkan dapat bersaing dengan kompetitor lainnya.

Pelatihan dilakukan dalam rangka meningkatkan keterampilan dan pengetahuan wanita pesisir namun tidak semua orang perlu dilatih, dan ketepatan pemilihan peserta pelatihan sangat menentukan keberhasilan pelatihan. Indikator orang/masyarakat yang perlu dilatih, adalah: (1) adanya kesenjangan pengetahuan, keterampilan dan sikap perilaku untuk melaksanakan pekerjaan tertentu; (2) menghadapi perubahan adanya teknologi baru; (3) adanya kebijakan/aturan baru; (4) hasil pekerjaan/usaha kurang optimal; (5) banyak potensi sumberdaya yang pemanfaatannya belum optimal, (Maryuto, 2015).

Pasca pelatihan perlu ada evaluasi minimal 3 (tiga) bulan setelah purnawidya mengikuti suatu pelatihan. Hal ini bertujuan untuk mengetahui sejauh mana peserta pelatihan dapat merasakan kegunaan (outcome) pelatihan yang telah meningkatkan kegiatan usahanya. Tingkat keberhasilan pelaksanaan pelatihan dapat diukur melalui indikator meningkatnya keterampilan dan pengetahuan wanita pesisir yang diterapkan dalam kegiatan usahanya.

Kerangka pikir pada penelitian ini meliputi tahapan pelaksanaan pelatihan kepada kelompok wanita pesisir, tahapan penerapan pengetahuan dan keterampilan pada kegiatan usaha yang dilakukan oleh kelompok wanita pesisir di daerahnya masing-masing, - tahapan kegiatan usaha yang mengalami kemajuan sebagai hasil penerapan pengetahuan dan keterampilan seusai mengikuti pelatihan, - tahapan terciptanya persepsi kelompok wanita pesisir yang usahanya mengalami peningkatan. 


\section{BAHAN DAN METODE}

\section{Lokasi Penelitian}

Penelitian dilaksanakan mulai bulan Maret - Agustus 2017 di Provinsi
Aceh, Sumatera Utara, Riau, dan Kepulauan Riau yang meliputi 27 (dua puluh tujuh) kabupaten/kota di wilayah kerja Balai Pelatihan dan Penyuluhan Perikanan (BPPP) Medan.

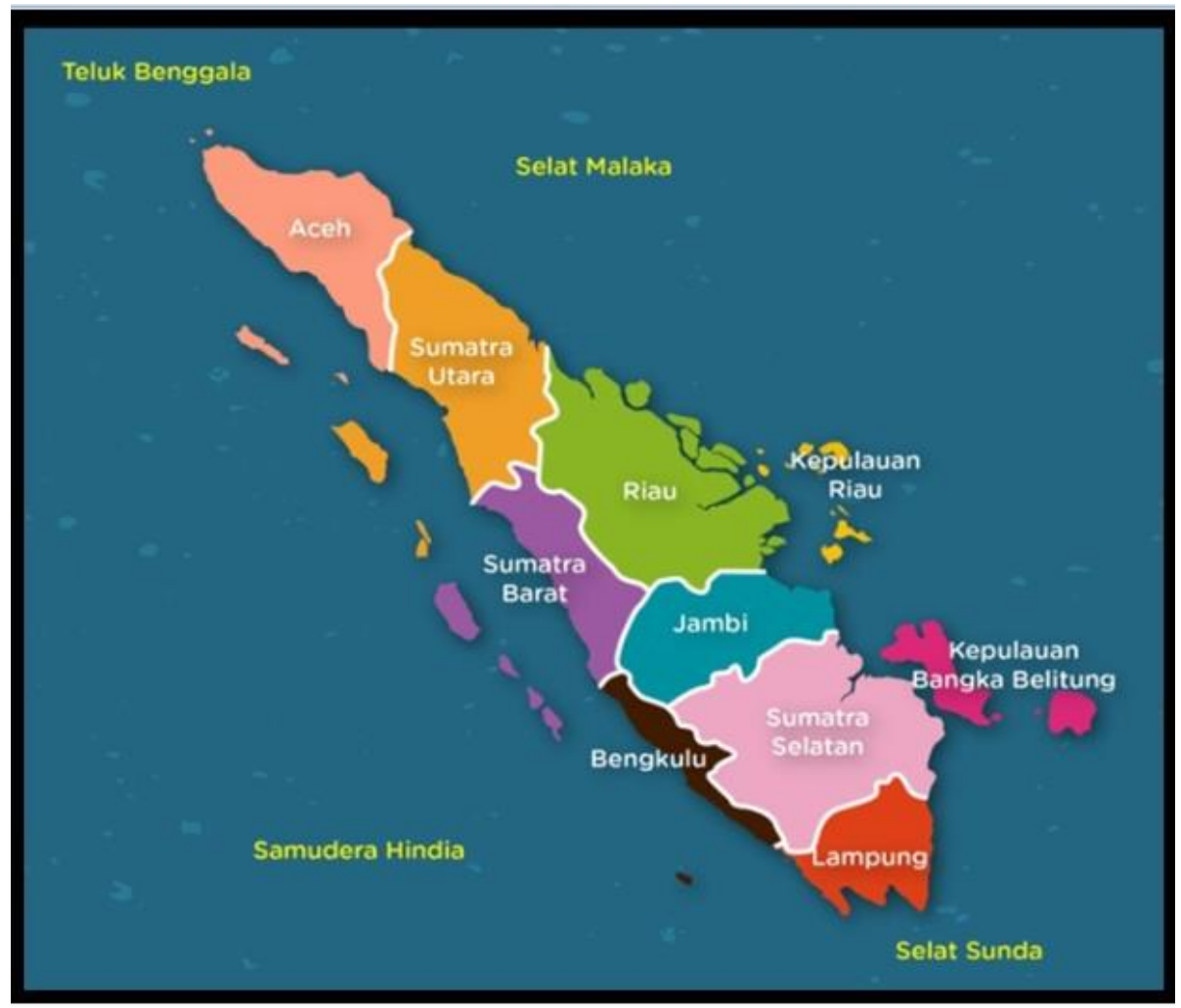

Sumber: https://beritaku.id/mengenal-pulau-sumatera-dengan-suku-melayu-yang-mendominasi

Gambar 2. Peta Lokasi Penelitian Prov.Aceh, Sumatera Utara, dan Riau/Kepulauan Riau Figure 2. Map of Research Location Provinsi Aceh, North Sumatera and Riau/Riau Islands

\section{Populasi dan Sampel}

Populasi sebagai suatu subjek yang diteliti merupakan mantan peserta pelatihan pengolahan hasil perikanan yang dilaksanakan oleh BPPP Medan pada tahun 2015-2016 dengan jumlah 596 (lima ratus sembilan puluh enam) orang yang berasal dari Provinsi Aceh, Sumatera Utara, dan Riau/Kepulauan Riau. Sebagian dari populasi ditetapkan sebagai sampel dengan responden sebanyak 278 (dua ratus tujuh puluh delapan) orang dan dilakukan kunjungan langsung ke lokasi tempat tinggal atau tempat usahanya oleh petugas lapangan. Akdon \& Hadi (2005:96) menyatakan bahwa "sampel adalah bagian dari populasi (sebagian atau wakil populasi yang diteliti)". Pemilihan lokasi asal peserta pada ke empat Provinsi lokasi penelitian didasarkan pada keterwakilan wilayah kerja Balai Diklat Perikanan Medan pada 27 (dua puluh tujuh) Kabupaten/Kota.

Tahapan pemilihan sampel secara sengaja (purposive sampling) dilakukan dengan cara menyampaikan lembaran evaluasi berupa kuesioner kepada 400 (empat ratus) orang mantan peserta pelatihan pengolahan hasil perikanan di 27 (dua puluh tujuh) kabupaten/kota dengan mendatangi langsung ke lokasi mantan peserta pelatihan tahun 2015- 
2016 dan pada batas waktu yang ditentukan terkumpul 278 (dua ratus tujuh puluh delapan) sampel yang akan di uji. Sugiyono (2000:97) menyatakan bahwa "Makin besar jumlah sampel mendekati populasi, maka peluang kesalahan generalisasi semakin kecil, dan sebaliknya makin kecil jumlah sampel menjauhi populasi, maka semakin besar kesalahan generalisasi”.

Penilaian terhadap kuesioer dilakukan dengan menggunakan skala score 1-4 yang selanjutnya diperoleh besaran/persentasi dari masing-masing komponen kuesioner.

\section{Pengumpulan Data}

Pengumpulan data dengan menggunakan sumber primer dan sumber sekunder dengan cara interview (wawancara), kuesioner (angket), observasi (pengamatan) dan gabungan dari ketiganya. Pengumpulan data dilakukan dengan model evaluasi pasca pelatihan dengan perangkat kuesioner dan wawancara langsung terhadap peserta pelatihan tahun 2015-2016.

Analisis data dilakukan dengan mengelompokkan data, mentabulasi data, menyajikan data tiap variabel yang diteliti dan melakukan perhitungan.

Tabel 1. Data Peserta Pelatihan Pengolahan Hasil Perikanan Wanita Pesisir Provinsi Aceh, Sumatera Utara dan Riau/Kepulauan Riau, BPPP Medan Tahun 2015-2016

Table 1. Participants in the Training of Fisheries Product Processing of Coastal Women in Aceh, North Sumatera and Riau/Riau Islands, BPPP Medan in 2015-2016

\begin{tabular}{|c|c|c|c|}
\hline No & Provinsi & $\begin{array}{c}\text { Jumlah Peserta } \\
\text { (orang) }\end{array}$ & $\begin{array}{c}\text { Jumlah Sampel } \\
\text { (orang) }\end{array}$ \\
\hline 1 & Aceh & 145 & 67 \\
\hline 2 & Sumatera Utara & 181 & 85 \\
\hline 3 & Riau/Kepulauan Riau & 270 & 126 \\
\hline & Jumlah & 596 & 278 \\
\hline
\end{tabular}

Sumber: Laporan Kinerja BPPP Medan Tahun 2015 dan 2016

\section{HASIL DAN BAHASAN}

HASIL

\section{Persepsi Responden Pasca Pelatihan}

Hasil pengamatan responden pasca pelatihan pengolahan hasil perikanan Provinsi Aceh, Sumatera Utara, dan Riau/Kepulauan Riau memperlihatkan bahwa sebanyak $71,2 \%$ responden menyatakan bahwa materi pelatihan sangat bermanfaat dan dapat diterapkan dalam usaha pengolahan ikan, sebanyak $69,7 \%$ responden sudah memanfaatkan kelembagaan ekonomi, dan sebanyak $78,4 \%$ responden menyatakan bahwa mereka memperoleh dampak ekonomi berupa adanya kenaikan pendapatan di atas rata-rata UMR provinsi tahun 2017 (Tabel 2). Rata-rata pendapatan wanita pesisir Prov Aceh Rp 2.791.000,- dengan UMR Rp 2.500.000,-; Prov Sumatera
Utara Rp 2.152.500,- dengan UMR Rp 1.961.354,-; dan Prov Riau Rp 2.825.200,- dengan UMR Rp 2.318.454. Pada tahun 2015 pendapatannya kurang dari UMR yang berlaku saat itu yaitu; Prov. Aceh Rp 1.900.000,-; Prov Sumatera Utara Rp 1.625.000,-; dan Riau/Kepulauan Riau Rp 1.878.000,(Tabel 4).

Besaran kompetensi yang dapat diaplikasikan (Tabel 3) pada kelompok I tidak ada responden (0\%) yang mengatakan tidak ada kompetensi yang dapat diaplikasikan dalam usaha pengolahan ikan. Hal ini menunjukkan bahwa kompetensi yang diperoleh selama pelatihan bermanfaat dan dapat diaplikasikan pada kegiatan usahanya. Pada kelompok II ada 46 responden $(16,54 \%)$ yang mengatakan hanya sebagian kecil kompetensi dapat 
diaplikasikan dalam kegiatan usahanya yang berarti bahwa sebagian besar kompetensi yang diperoleh belum bisa diaplikasikan langsung pada kegiatan usahanya. Pada kelompok III ada 197 responden $(70,86 \%)$ yang merupakan bagian terbesar yang menyatakan bahwa sebagian besar kompetensi dapat diaplikasikan dalam usaha pengolahan ikan. Pada kelompok IV terdapat 25 responden $(12,58 \%)$ yang menyatakan bahwa seluruh kompetensi dapat diaplikasikan dalam usaha pengolahan ikan.

Tabel 2. Data Hasil Evaluasi Pasca Pelatihan Wanita Pesisir Provinsi Aceh, Sumatera Utara, dan Riau /Kepulauan Riau Tahun 2015-2016

Table 2. Data of the Results of Post-Training Evaluation of Coastal Women in the Provinces of Aceh, North Sumatra, and Riau/Riau Islands in 2015-2016

\begin{tabular}{|c|c|c|c|}
\hline No & Tingkat Manfaat/Dampak & $\begin{array}{c}\text { Jumlah Data Responden } \\
\text { Yang Masuk } \\
\text { (Orang) }\end{array}$ & $\begin{array}{c}\text { Prosentasi } \\
\text { Jawaban Responden }\end{array}$ \\
\hline 1 & $\begin{array}{l}\text { Manfaat materi pelatihan dan penerapannya } \\
\text { dalam usaha pengolahan ikan wanita pesisir }\end{array}$ & 278 & $\begin{array}{c}71,2 \% \\
\text { sangat bermanfaat dan } \\
\text { diterapkan }\end{array}$ \\
\hline 2 & $\begin{array}{l}\text { Kontribusi hasil pelatihan terhadap } \\
\text { peningkatan kegiatan usaha dan pendapatan } \\
\text { purnawidya: }\end{array}$ & 278 & $\begin{array}{c}78,4 \% \\
\text { Sangat berkontribusi }\end{array}$ \\
\hline 3 & $\begin{array}{l}\text { Pendapatan rata-rata wanita pesisir per Juni } \\
2017\end{array}$ & 278 & $\begin{array}{l}42,08 \% \text { berpendapatan } \\
\text { Rp } 2,5-3 \mathrm{jt} / \mathrm{bln}\end{array}$ \\
\hline 4 & $\begin{array}{l}\text { Dalam mengembangkan usaha, khusus } \\
\text { untuk permodalan dan manajemen, } \\
\text { memanfaatkan kelembagaan ekonomi }\end{array}$ & 278 & $\begin{array}{l}69,7 \% \\
\text { memanfaatkan lembaga } \\
\text { ekonomi }\end{array}$ \\
\hline
\end{tabular}

Tabel 3. Data Pengaplikasian Kompetensi Responden Sebagai Manfaat Pelatihan Table 3. Data on the Application of Respondents' Competencies as Benefits of Training

\begin{tabular}{|c|c|c|c|c|c|c|}
\hline \multirow[b]{2}{*}{ No } & \multirow{2}{*}{$\begin{array}{l}\text { Manfaat materi pelatihan dan } \\
\text { penerapannya dalam usaha } \\
\text { pengolahan ikan wanita pesisir }\end{array}$} & \multicolumn{4}{|c|}{ Jumlah responden } & \multirow[b]{2}{*}{$\begin{array}{c}\text { Jumlah/persentase } \\
\text { responden }\end{array}$} \\
\hline & & Aceh & Sumut & Riau & Kepri & \\
\hline 1 & $\begin{array}{l}\text { Tidak ada kompetensi yang dapat } \\
\text { diaplikasikan dalam usaha pengolahan } \\
\text { ikan }\end{array}$ & - & - & - & - & - \\
\hline 2 & $\begin{array}{l}\text { Sebagian kecil kompetensi dapat } \\
\text { diaplikasikan dalam usaha pengolahan } \\
\text { ikan }\end{array}$ & 11 & 14 & 11 & 10 & $16,54 \%$ \\
\hline 3 & $\begin{array}{l}\text { Sebagian besar kompetensi dapat } \\
\text { diaplikasikan dalam usaha pengolahan } \\
\text { ikan }\end{array}$ & 48 & 60 & 45 & 44 & $70,86 \%$ \\
\hline 4 & $\begin{array}{l}\text { Seluruh kompetensi dapat diaplikasikan } \\
\text { dalam usaha pengolahan ikan }\end{array}$ & 8 & 11 & 8 & 8 & $12,58 \%$ \\
\hline & Jumlah & 67 & 85 & 64 & 62 & $100 \%$ \\
\hline
\end{tabular}


Tabel 4. Pendapatan Rata-rata Wanita Pesisir per Juni 2017 dibandingkan dengan Upah Minimal Regional (UMR) Provinsi Tahun 2017

Table 4. The Average Income of Coastal Women as of June 2017 compared to the Provincial Minimum Wage (UMR) in 2017

\begin{tabular}{|c|c|c|c|c|c|}
\hline No & Provinsi & $\begin{array}{l}\text { Pendapatan Rata- } \\
\text { rata/bulan Tahun } \\
2015\end{array}$ & $\begin{array}{c}\text { Pendapatan } \\
\text { Rata-rata/bulan } \\
\text { (per Juni 2017) }\end{array}$ & $\begin{array}{l}\text { UMR Provinsi } \\
\text { Tahun 2015* }\end{array}$ & $\begin{array}{l}\text { UMR Provinsi } \\
\text { Tahun 2017* }\end{array}$ \\
\hline 1 & Aceh & $<\operatorname{Rp} 1.900 .000$ & Rp 2.791.000 & Rp 1.900.000 & Rp 2.500.000 \\
\hline 2 & Sumatera Utara & $<\operatorname{Rp} 1.625 .000$ & Rp 2.152.500 & Rp 1.625.000 & $\operatorname{Rp} 1.961 .354$ \\
\hline 3 & $\begin{array}{c}\text { Riau/Kepulauan } \\
\text { Riau }\end{array}$ & $<\operatorname{Rp} 1.878 .000$ & $\mathrm{Rp} 2.825 .200$ & Rp 1.878.000 & $\mathrm{Rp} 2.318 .454$ \\
\hline
\end{tabular}

Sumber: BPS (2017)

\section{BAHASAN}

Manfaat Materi Pelatihan

Dalam perencanaan pelatihan dilakukan identifikasi kebutuhan pelatihan, dari hasil kegiatan ini dapat diidentifikasi materi pelatihan yang akan dilatihkan pada peserta, dituangkan dalam kurikulum pelatihan. Sebanyak $71,2 \%$ responden menyatakan bahwa materi pelatihan sangat bermanfaat dan dapat diterapkan dalam usaha pengolahan ikan, hal ini menunjukkan bahwa penetapan kurikulum dan pemilihan peserta pelatihan sudah tepat. Hal ini sesuai dengan kegiatan pelatihan sebagai suatu proses belajar yang dimaksudkan untuk mengubah kompetensi kerja seseorang sehingga ia dapat berprestasi lebih baik dalam jabatan/usahanya, (BPSDM-KP, 2006).

Wanita pesisir yang mengikuti pelatihan merasakan manfaat materi yang diberikan pada saat pelatihan di bidang pengolahan hasil perikanan. Melalui pelatihan kompetensinya meningkat sehingga dapat diiplementasikan dalam melakukan kegiatan usahanya. Hal ini ditunjukkan dengan tidak adanya responden $(0 \%)$ dari ke empat lokasi penelitian yang mengatakan bahwa kompetensi yang diperoleh tidak dapat diaplikasikan dalam usaha pengolahan ikan yang dilakukannya. Jadi kompetensi yang diperoleh melalui materi-materi pelatihan cukup bermanfaat dan dapat diaplikasikan pada kegiatan usaha mereka.

\section{Manfaat ekonomi}

Pemberian kesempatan kepada wanita pesisir untuk mengikuti pelatihan sesuai dengan bidang usahanya memberikan hasil yang berdampak kepada peningkatan pengetahuan sehingga mereka dapat menerapkan hasil pelatihan pada kegiatan usahanya dan pendapatannya menjadi meningkat. Kegiatan usaha yang dilakukan wanita pesisir menjadi lebih efektif dan eifsien dalam prosesnya. Hal ini di lihat dari adanya peningkatan hasil usaha pada tahun 2017 yang telah melebihi upah minimal regional di masing-masing wilayah Provinsi. Harini (2014:78), menyatakan bahwa pelaku usaha setelah pelatihan menjadi lebih kreatif dan inovatif menciptakan atau mengembangkan produk yang dihasilkan. Peningkatan kompetensi melalui pelatihan berguna untuk mengembangkan usahanya yang akan berdampak pada kenaikan pendapatan. Sebanyak 78,4 \% responden menyatakan memperoleh dampak ekonomi berupa adanya kenaikan pendapatan di atas ratarata UMR provinsi tahun 2017. Dapat dikatakan bahwa wanita pesisir di provinsi tersebut mempunyai pendapatan di atas rata-rata UMR provinsi. Hal ini sesuai dengan Puspita \& Widanta (2016), yang mengatakan bahwa, pelatihan 
memiliki hubungan yang signifikan terhadap pendapatan istri nelayan, jika istri nelayan sering mendapat pelatihan dari pemerintah maka akan banyak keterampilan yang dimiliki guna meningkatkan pendapatan keluarga.

\section{Manfaat sosial}

Kelembagaan ekonomi seperti
perbankan dan koperasi sangat
menentukan kecepatan berkembangnya usaha perikanan di suatu wilayah, khusunya dalam hal pengembangan permodalan. Tersedianya kelembagaan ekonomi di sentra-sentra kegiatan usaha wanita pesisir dapat dimanfaatkan dan sebanyak $69,7 \%$ responden sudah memanfaatkan kelembagaan tersebut. Manfaat sosial yang diperoleh dengan memanfaatkan lembaga ekonomi dapat meningkatkan kelancaran usaha dan mempunyai prospek yang baik kedepannya. Hal ini sesuai dengan Bank Indonesia (2017), bahwa terdapat peningkatan persepsi masyarakat pesisir terkait kemudahan akses perbankan, keamanan menggunakan jasa perbankan, adanya pertumbuhan dana yang disimpan di bank, serta keekonomian penggunaan jasa perbankan.

Persepsi wanita pesisir setelah mengikuti pelatihan (Tabel 3) di masingmasing lokasi penelitian menunjukkan bahwa di wilayah Provinsi Sumatera Utara baik pada sub kriteria sebagian kecil (14 orang), sub kriteria sebagian besar (60 orang) dan sub kriteria seluruh kompetensi yang dapat di aplikasikan (11 orang), memiliki responden lebih banyak persepsinya terhadap manfaat pelatihan di banding yang berasal dari Provinsi Aceh, Provinsi Riau/Kepulauan Riau dalam hal mengaplikasikan kompetensinya pada kegiatan usahanya. Hal ini tidak terlepas dari dukungan Pemerintah Provinsi Sumatera Utara dan Pemerintah Kabupaten/Kota melalui program-program peningkatan kegiatan usaha wanita pesisir dalam bidang pengolahan hasil perikanan. baik melalui pelatihan, bimbingan teknis maupun pemagangan. Disisi lain lokasi Balai Diklat Perikanan yang berada di wilayah kota Medan memudahkan wanita pesisir untuk mengikuti pelatihan, bimbingan teknis dan konsultasi teknis serta konsultasi usaha sehingga mereka lebih memiliki persepsi yang kuat terhadap peningkatan kompetensi sebagai manfaat pelatihan.

\section{SIMPULAN}

Peningkatan kompetensi wanita pesisir yang dapat diaplikasikan pada kegiatan usaha di bidang pengolahan hasil perikanan merupakan manfaat materi pelatihan yang diperoleh melalui pelatihan. Dalam hal meningkatnya kegiatan usaha sekaligus meningkatnya pendapatan wanita pesisir merupakan manfaat ekonomi yang diperoleh setelah menerapkan kompetensinya pada kegiatan usahanya. Manfaat lain yang diperoleh wanita pesisir adalah manfaat sosial dimana wanita pesisir telah dapat memanfaatkan kelembagaan keuangan Bank dan/atau Koperasi yang berada di sentra-sentra kegiatan usaha perikanan.

\section{DAFTAR PUSTAKA}

Akdon, A. dan Sahlan Hadi. (2005). Aplikasi statistika dan metode penelitian untuk administrasi dan manajemen. Dewa Ruchi. Bandung.

[BPSDM-KP] Badan Pengembangan Sumber Daya Manusia-Kelautan dan Perikanan. (2006). Pedoman Penyelenggaraan Pelatihan Kelautan dan Perikanan. BPSDMKP. Jakarta.

[BPPP] Balai Pendidikan dan Pelatihan Perikanan. (2016). Laporan Tahunan. BPPP, Medan.

[BPS] Badan Pusat Statistik. (2017). Upah Minimum Regional/Propinsi Seluruh Indonesia. BPS. Jakarta. 
Bank Indonesia. (2017). Pilot Project Peningkatan Akses Jasa Keuangan pada Kelompok Masyarakat Pesisir Sektor Perikanan Tangkap. Departemen Pengembangan UMKM, BI. Jakarta.

Harini, S. (2014). Pengaruh Pelatihan Entrepreneurship dan Manajemen Usaha terhadap Pendapatan Usaha Mikro Makanan dan Minuman. Jurnal Entrepreneur dan Entrepreneurship, 3 (1 \& 2): 73-80.

Maryuto, H. (2015). Manajemen Pelatihan. Jurusan Penyuluhan Perikanan, Sekolah Tinggi Perikanan. Bogor.
Puspita, L. M. R., \& Widanta, A. A. B. P. (2016). Analisis Pendapatan Istri Nelayan Dalam Upaya Meningkatkan Pendapatan Keluarga. e-Jurnal Ekonomi Pembangunan, 5 (7): 846-860.

Raodah. (2013). Peranan Istri Nelayan dalam Meningkatkan Ekonomi Keluarga di Kelurahan Lapulu Kota Kendari Provinsi Sulawesi Tenggara. Jurnal Bina Praja Makasar, 5 (2): 79-90.

Sugiyono. (2000). Statistik Untuk Penelitian. Alfabeta. Bandung. 